\title{
Association of HSV1/2 Infection and Pemphigus Disease
}

\author{
Mohammad Rahmati-Roodsari ${ }^{1}$, Saeid Reza Rahmdar ${ }^{1}$, Mohammed Alfaragi ${ }^{2}$, Moham- \\ mad Saeedi ${ }^{2, *}$, Sara Rahmati Roodsari ${ }^{3}$, Raheleh Sadat Sajadi Nia ${ }^{1}$
}

${ }_{1}^{1}$ Shahid Beheshti University of Medical Sciences, Tehran, IR Iran

${ }^{2}$ Skin Research Center, Shahid Beheshti University of Medical Sciences, Tehran, IR Iran

3 Infectious Diseases and Tropical Medicine Research Center, Shahid Beheshti University of Medical Sciences, Tehran, IR Iran

${ }^{*}$ Corresponding author: Mohammad Saeedi, Skin Research Center, Shahid Beheshti University of Medical Sciences, Tehran, IR Iran. Tel: +98-2177862865, Fax:+98-2122741508, E-mail: msaeedimd@gmail.com.

Received: June 13, 2013; Revised: July 21, 2013; Accepted: October 19, 2013

\begin{abstract}
Background: Pemphigus is known as an autoimmune bullous disease of the skin and mucous membranes that is relatively prevalent in Iran. The herpes virus is one of the suspected factors that might have role in induction or exacerbation of pemphigus. Objectives: Present study was performed to assess the prevalence of HSV1/2 infection in pemphigus patients referred to Shohadae-Tajrish and Loghman-e-Hakim hospitals during 2010-2011.

Patients and Methods: Forty pemphigus patients enrolled in the study. A lesional skin or mucosal biopsy was taken from each patient and analyzed by PCR for detection of HSV1/2. The PCR results were positive or negative, and then the frequency of HSV1/2 infections in pemphigus patients was calculated.

Results: Ten patients (25\%) had a history of orolabial herpes infection. The results of all samples were negative for HSV1 except one sample which showed the positive result for HSV2 in a patient with history of herpes infection. He was considerably resistant to treatment pemphigus vulgaris with about 60 skin lesions and 20 mucosal lesions. Adding Acyclovir to his treatment regime for ten days resulted in full recovery.

Conclusions: Prevalence of HSV1/2 in mucocutaneous biopsies from pemphigus patients is $2.5 \%$ and possibly HSV1/2 has no role in the pathogenesis of pemphigus lesions. But resistant cases to treatment might be suspected to HSV.
\end{abstract}

Keywords: Herpes Simplex virus; Pemphigus; Prevalence

\section{Background}

Several investigators suggested a trigger role for viral infections in development of several autoimmune diseases such as rheumatoid arthritis, lupus erythematous and multiple sclerosis. For many years, it was assumed that viral infection, especially Herpes virus may have role in induction or exacerbation of pemphigus patients. Physicians have tried to find virus in blood and mucocutaneous lesions of pemphigus patients (1-3). Several previous studies reported that viral infections including Herpes simplex virus (HSV), Varicella zoster virus (VZV), Epstein-Barr virus (EBV), Cytomegalovirus (CMV), Human Herpes virus 8 (HHV 8) and Human Immunodeficiency virus (HIV) may have trigger role in activation or exacerbation of pemphigus.

Initially, Karin in 1974, reported two HSV patients in a study on 59 pemphigus patients (4). Ruocco et al. reported that of ten pemphigus patients, who had HSV associated with their diseases, seven patients had positive viral culture and two patients had positive serology(5). Tufano et al. used PCR for detecting HSV1/2 DNA sequence in pe- ripheral blood smear sample and skin lesions of pemphigus patients (6).

It has been tried to perform several procedures such as viral culture or polymerase chain reaction (PCR) for detection of an infective agents in patients with pemphigus. We have not yet found any causative factor for pemphigus.

\section{Objectives}

Present study was performed for assessment of HSV1/2 in skin or mucosal lesions of patients with pemphigus using PCR procedure in Shohada-e-Tajrish and Loghman Hakim hospitals.

\section{Patients and Methods}

This cross sectional study was performed from September 2010 to November 2011 on patients with pemphigus in two skin clinics of Shohada-e-Tajrish and Loghman Hakim hospitals. Forty patients were included into the study. Diagnosis was confirmed by histologic and direct immunofluorescence (DIF) studies in new cases. Patients

Implication for health policy/practice/research/medical education:

This study is performed to evaluate the role of HSV1/2 in induction and exacerbation of pemphigus vulgaris.

Copyright (C) 2014, Pediartric Infections Research Center. This is an open-access article distributed under the terms of the Creative Commons Attribution License, which permits unrestricted use, distribution, and reproduction in any medium, provided the original work is properly cited. 
who used Captopril or Penicillamin were excluded from the study.

Severity of pemphigus was assessed according to Dr. Victoria's classification (by number, location and type of lesions) and patients were classified as mild, moderate and severe types $(7,8)$.

\subsection{Sample Preparing and PCR Procedure}

A lesional sample was taken with punch biopsy from bullae or skin erosions or bucal mucosa and was sent in normal salin medium for real-time PCR to the standard laboratory in Tehran. High purified DNA was extracted, washed with buffer and maintained at $-20^{\circ} \mathrm{C}$ before PCR procedure. According to the producer, company recommendation, buffer, $0.5 \mu \mathrm{mol} / \mathrm{L}$ primer, $200 \mathrm{dNTP} \mu \mathrm{mol} / \mathrm{L}$, $1.2 \mu \mathrm{mol} / \mathrm{L} \mathrm{MgCl}$ and $0.5 \%$ betaien with DNA polymerase enzyme were inserted in several temperatures for completion of PCR cycle.

For HSV1/2 determination, 5-TACATCGGCGTCATCTGCGGGG-3' and 5'-CAGTTCGGTGAGGACAAAG-3' were used. PCR products were transferred on Agar gel containing Ethidiumbromid 2\%. Positive control test was performed on HSV1/2 containing clone for accuracy confirmation of PCR procedure. Negative control was performed on healthy general population.

\subsection{Statistical Analysis}

Study data were analyzed with SPSS version 19.0 and qualitative variables were presented with frequencies and quantitative ones were presented with mean and standard deviation. T-test and Chi-square statistical tests were used for data analysis with $95 \%$ accuracy level. P-values which were less than 0.05 were considered statistically significant.

\section{Results}

Forty pemphigus patients ( 26 female) enrolled in the study. Mean age of patients was 45.85 (23-69) years. Pemphigus vulgaris was seen in 38 (95\%) patients and pemphigus foliaceus was observed only in $2(5 \%)$ patients. According to Dr. Victoria's classification for pemphigus intensity, 27 (67.5\%) patients were in mild, 8 (20\%) patients in moderate and $5(12.5 \%)$ were in severe group.

HSV positive result was observed only in one patient. He was a 61 years old male with positive PCR for HSV2 of his abdominal skin lesion and negative for HSV1. He had a severe disease and highly resistant to treatment. Despite receiving $2 \mathrm{mg} / \mathrm{kg}$ of prednisolone, the sign of improvements was not observed. Adding acyclovir for ten days $(400 \mathrm{mg} / \mathrm{TDS})$ resulted in full recovery.

Results of PCR procedure in all of mild and moderate patients were negative for both of HSV1 and HSV2 lesions. HSV2 was positive only in one patient with severe intensity and HSV1 were negative in all of patients with severe pemphigus. Pemphigus intensity had significant with results of PCR procedure $(\mathrm{P}=0.02)$ but prevalence of HSV $1 / 2$ had no significant association with type of pemphigus lesions.

Thirty seven (92.5\%) patients were new cases and had not received treatment at the time of biopsy and diagnosis. One patient (23 years old women) was treated with Prednisolone $50 \mathrm{mg} / \mathrm{d}$ and Azathioprine $50 \mathrm{mg} / \mathrm{BD}$ for a month and the diseases recurrence occurred in her mucosal lesions and one patient (46 years old women) was treated with prednisolone $10 \mathrm{mg} / \mathrm{d}$ and had recurrence since last three weeks. Two female patients had negative results in PCR procedure for HSV1/2. Skin pemphigus vulgaris had suddenly recurred in a 52 male patient who was under the control since last year and at the time of study, he did not receive any treatment. He had negative PCR results for HSV1/2. All of patients with past history of pemphigus were categorized as the newly- diagnosed patients and did not receive any immunosuppressive treatment and HSV2 result was positive only in one of them and HSV1 was negative in all of patients.

Treatment with immunosuppressive agents had not significant association with incidence of HSV1/2 in included patients. Among 40 pemphigus patients, 10 (25\%) patients had genital or bucal herpes signs and one of them had positive result of HSV2 in PCR procedure. History of herpes involvement in study patients had no significant association with results of PCR procedure (Table 1).

\section{Discussion}

Immunohistochemistry, electronic microscopic study, specific antigen detection and culture of virus were suggested for diagnosis of viral infection. Culture of virus has more sensitivity in vesicular lesions of primary disorders in immunosuppressive patients. The main advantage of PCR is independency of microbial infection in tissue samples. PCR results are prepared in one day and are suitable for patients with severe disorders without time saving for diagnosis with culture of virus or other methods (9). Due to the high rate of false positive in this method, results must be confirmed according to clinical pattern of the disease.

Mean age in our study was about 46 years old and was lower than global age range (50-60 years old) of pemphigus patients. Only Indian patients have lower age of onset for pemphigus than Iranian patients (10). Mean age of Iranian patients in another study in Razi Hospital was also lower than global age indicated that Iranian pemphigus patients had lower age of onset than people of western countries (11). Female patients consisted $65 \%$ of our patients and this rate was similar to results of other epidemiological studies (12).

Role of viral infection in pemphigus pathogenesis has been assessed in some other studies. Theoretically, it was believed that infections can induce autoimmunity by 
Rahmati-Roodsari Met al.

\begin{tabular}{|c|c|c|c|c|}
\hline & No. (\%) & HSV1 & HSV2 & P Value \\
\hline Type of pemphicus & & & & 0.82 \\
\hline Vulgaris & $38(95)$ & - & 1 & \\
\hline Foliaceous & $2(5)$ & - & - & \\
\hline Sex & & & & 0.17 \\
\hline Female & $26(65)$ & - & - & \\
\hline Male & $14(35)$ & - & 1 & \\
\hline Biopsy location & & & & 0.89 \\
\hline Mucosal & $7(17.5)$ & - & - & \\
\hline Skin & $33(82.5)$ & - & 1 & \\
\hline Disease intensity & & & & 0.028 \\
\hline Mild & $27(67.5)$ & Negative & Negative & \\
\hline Moderate & $8(20)$ & Negative & Negative & \\
\hline Severe & $5(12.5)$ & Negative & Positive & \\
\hline Involvement type & & & & 0.78 \\
\hline Mucosal & $7(17.5)$ & Negative & Negative & \\
\hline Skin & $6(15)$ & Negative & Negative & \\
\hline Skin-mucosal & $27(67.5)$ & Negative & Negative & \\
\hline Treatment type & & & & 0.95 \\
\hline $\begin{array}{l}\text { Corticosteroid } \\
\text { therapy }\end{array}$ & $2(5)$ & Negative & Negative & \\
\hline $\begin{array}{l}\text { Stop corticoste- } \\
\text { roid therapy }\end{array}$ & $1(2.5)$ & Negative & Negative & \\
\hline New cases & $37(92.5)$ & Negative & Positive & \\
\hline Past history of herpes & & & & 0.08 \\
\hline Yes & $10(25)$ & Positive & Negative & \\
\hline No & $30(75)$ & Negative & Negative & \\
\hline
\end{tabular}

some pathways such as activation of antigen presenting cells and activation of Toll like receptors $(4,13,14)$. Role of HSV in pathogenesis of pemphigus is challenging. In some pemphigus patients, HSV infection can induce recurrence of their lesions. Cross reaction between viral antigens and host antigens and changing in immune system due to viral infection can induce the recurrence (10). Prevalence of HSV1/2 in our patients was $2.5 \%$. This low prevalence shows that HSV1/2 probably has no role in pemphigus pathogenesis.

Although one patient with positive findings for HSV2 in PCR procedure had positive history of herpes involvement, this history was not associated with findings of PCR procedure. In similar study in Razi Hospital in Tehran, there was higher rate of positive history compared with present study, but none of them had positive findings in PCR procedure for HSV (15). Although HSV1/2 infection is common infection, detecting DNA of virus in blood vessel samples has been occurred rarely in few people and was not suitable for virus detection (16). We used DNA detection in skin lesions because it had been proved in some of previous study as suitable marker in some viral disorders such as Erythema multiform and Herpes simplex (17).

In the study of Marzano similar to ours, only one of 33 patients has positive PCR for HSV (18). Differences in prevalence of HSV are also related to sampling method. It is believed that skin dermal layer had higher frequency of virus compared with epidermal layer (19).

Present study had some limitations; first of all; we evaluated only two types of pemphigus disorders and due to lower prevalence of other pemphigus types, we could not prepare enough sample size from other types. Next, we had performed only PCR procedure for study samples without any serological evaluation, we thought that due to wide spectrum of changes and non-specificity for skin lesions, serological assessments was not suitable for accurate method such as PCR. Third; we had not evaluated other viruses that might have role in pemphigus pathogenesis. Fourth; due to the role of genetic factor that had impact on immune system in virus pathogenesis, HLA 
assessment in patients with HSV positive and comparing them with other patients will be our purpose.

Conclusions: Occult HSV infection in patients with bullous lesion is common phenomena might be evaluated in patients with treatment failure and recurrence of pemphigus. Although we didn't know that HSV colonization was considered as a source of coming infection (20), Physicians must distinguish between HSV colonization and active infection. Due to its specific situation, HSV, in most of case is underestimated (21). In patients who use immunosuppressive agents, severe form of HSV may occur. Topical corticosteroid in pemphigus patients can change the disorder and scar formation $(4,14,20)$.

\section{Acknowledgements}

This study was supported partially by a grant from Skin Research Center, Shahid Beheshti University of Medical Sciences and Shohada-e-Tajrish and Loghman-e- Hakim skin ward.

\section{Authors' Contribution}

All authors contributed equaln in this study.

\section{Financial Disclosure}

All authors have no conflicts of interest to declare and do not have any financial or non-financial conflicts of interest.

\section{Funding/Support}

There is no support for this study.

\section{References}

1. Ahmed AR, Rosen GB. Viruses in pemphigus. Int J Dermatol. 1989;28(4):209-17.

2. Angulo JJ. Attempts to isolate a virus from pemphigus foliaceus cases. AMA Arch Derm Syphilol. 1954;69(4):472-4.

3. Kopel D. Serologic reactions in pemphigus vulgaris; an attempt to detect auto-antibodies or a virus in the blood serum or blister fluid in pemphigus vulgaris. J Invest Dermatol. 1954;22(4):261-2.

4. Sagi L, Sherer Y, Trau H, Shoenfeld Y. Pemphigus and infectious agents. Autoimmun Rev. 2008;8(1):33-5.

5. Krain LS. Pemphigus. Epidemiologic and survival characteristics of 59 patients, 1955-1973. Arch Dermatol.1974;110(6):862-5.

6. Tufano MA, Baroni A, Buommino E, Ruocco E, Lombardi ML, Ruocco V. Detection of herpesvirus DNA in peripheral blood mononuclear cells and skin lesions of patients with pemphigus by polymerase chain reaction. Br J Dermatol.1999;141(6):1033-9.

7. Anyanwu C, Langenhan J, Werth VP. Measurement of disease severity in cutaneous autoimmune diseases. F1000Prime Rep. 2013;5:19.

8. Daniel BS, Hertl M, Werth VP, Eming R, Murrell DF. Severity score indexes for blistering diseases. Clin Dermatol. 2012;30(1):108-13.

9. Brandao ML, Fernandes NC, Batista DP, Santos N. Refractory pemphigus vulgaris associated with herpes infection: case report and review. Rev Inst Med Trop Sao Paulo. 2011;53(2):113-7.

10. Wilson C, Wojnarowska F, Mehra NK, Pasricha JS. Pemphigus in Oxford, UK, and New Delhi, India: a comparative study of disease characteristics and HLA antigens. Dermatology. 1994;189 Suppl 1:108-10.

11. Kalra A, Ratho RK, Kaur I, Kumar B. Role of herpes simplex and cytomegalo viruses in recalcitrant oral lesions of pemphigus vulgaris. Int J Dermatol. 2005;44(3):259-60.

12. Abdolsamadi HR, Abdollahzadeh S, Bakianian Vaziri P, Beheshti A, Shafigh E, Vahedi M. Epidemiology of pemphigus in tehran, iran: a 20-year retrospective study. J Dent Res Dent Clin Dent Prospects. 2007;1(3):108-13.

13. Brenner S, Sasson A, Sharon O. Pemphigus and infections. Clin Dermatol. 2002;20(2):114-8.

14. Shoenfeld Y, Gilburd B, Abu-Shakra M, AmitalH, Barzilai O, Berkun Y, et al. The mosaic of autoimmunity: genetic factors involved in autoimmune diseases--2008. Isr Med Assoc J. 2008;10(1):3-7.

15. Esmaili N, Hallaji Z, Abedini R, Soori T, Mortazavi H, ChamsDavatchi C. Pemphigus vulgaris and herpesviruses: is there any relationship? Int J Dermatol. 2010;49(11):1261-5.

16. Brice SL, Stockert SS, Jester JD, Huff JC, Bunker JD, Weston WL. Detection of herpes simplex virus DNA in the peripheral blood during acute recurrent herpes labialis. J Am Acad Dermatol. 1992;26(4):594-8.

17. Brice SL, Krzemien D, Weston WL, Huff JC. Detection of herpes simplex virus DNA in cutaneous lesions of erythema multiforme. J Invest Dermatol.1989;93(1):183-7.

18. Marzano AV, Tourlaki A, Merlo V, Spinelli D, Venegoni L, Crosti C Herpes simplex virus infection and pemphigus. Int J Immunopathol Pharmacol. 2009;22(3):781-6.

19. Kalter DC, Greenhouse JJ, Orenstein JM, Schnittman SM, Gendelman HE, Meltzer MS. Epidermal Langerhans cells are not principal reservoirs of virus in HIV disease. J Immunol. 1991;146(10):3396-404.

20. Nikkels AF, Delvenne P, Herfs M, Pierard GE. Occult herpes simplex virus colonization of bullous dermatitides. Am J Clin Dermatol. 2008;9(3):163-8.

21. Schlupen EM, Wollenberg A, Hanel S, Stumpenhausen G, Volkenandt M. Detection of herpes simplex virus in exacerbated pemphigus vulgaris by polymerase chain reaction. Dermatology. 1996;192(4):312-6. 